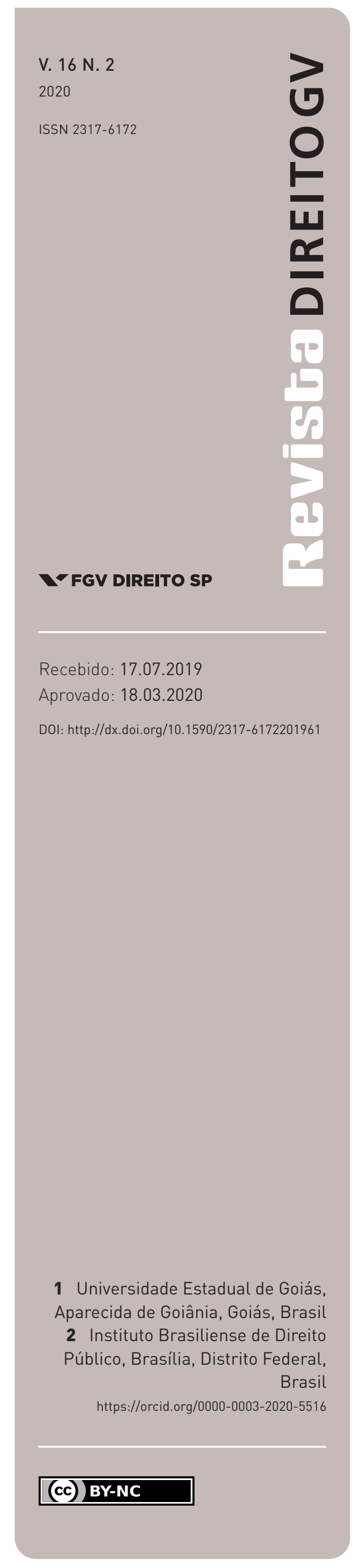

\section{Standard probatório para condenação e dúvida razoável no processo penal: análise das possíveis contribuições ao ordenamento brasileiro}

STANDARD OF PROOF TO CONVICTION AND REASONABLE DOUBT IN CRIMINAL PROCEDURE: ANALYSIS OF POSSIBLE CONTRIBUTIONS TO THE BRAZILIAN CRIMINAL JUSTICE

Vinicius Gomes de Vasconcellos ${ }^{\mathbf{1 , 2}}$

\section{Resumo}

Este artigo pretende analisar o standard probatório para condenação no processo penal brasileiro e as possíveis contribuições da categoria "além da dúvida razoável" em caso de incorporação ao sistema nacional. Trata-se de temática pertinente, tendo em vista a ausência de regulamentação expressa no ordenamento pátrio e a recente abordagem doutrinária sobre a temática. Assim, almeja-se responder aos seguintes problemas: 1) É necessário adotar um standard probatório para condenação no processo penal brasileiro? 2) 0 standard de “prova além da dúvida razoável" é uma opção viável e pertinente? 3) Quais critérios podem ser utilizados para a definição de seu conteúdo? Sustenta-se que a adoção de um standard probatório com critérios lógicos e objetivos é passo fundamental para a consagração de uma teoria racional da prova, de modo que, ainda que existam críticas relevantes, a categoria "além da dúvida razoável" pode aportar importantes contribuições ao processo penal brasileiro. Nesse sentido, este artigo propõe critérios para sua definição e apresenta sugestão de alteração legislativa.

\section{Palavras-chave}

Standard probatório; dúvida razoável; presunção de inocência; processo penal; valoração racional da prova.

\begin{abstract}
This article intends to analyze the standard of proof for conviction in Brazilian criminal procedure and the possible contributions of the "beyond reasonable doubt" category in case of incorporation into the national system. This is a relevant theme, due to the absence of express regulations in Brazilian legal order and the incipient doctrinal approach on the subject. Thus, it is intended to answer the following problems: 1) Is it necessary to adopt a standard of proof for conviction in the Brazilian criminal procedure? 2) Is the standard of "proof beyond reasonable doubt" a viable and pertinent option? 3) What criteria can be used to define its content? It is argued that the adoption of a standard of proof with logical and objective criteria is a fundamental step towards the implementation of a rational theory of proof, so that, although there are relevant criticisms, the "beyond reasonable doubt" category can provide important contributions to the Brazilian criminal procedure. In this sense, this article proposes criteria for its definition and suggests a legislative amendment.
\end{abstract}

\section{Keywords}

Standard of proof; reasonable doubt; presumption of innocence; criminal procedure; rational evidence evaluation. 


\section{INTRODUÇÃO}

Considerando-se que no processo penal ocorre a verificação de uma acusação a partir da reconstrução histórica de fatos passados, ${ }^{1}$ pode-se afirmar que "todo o processo gira em torno de uma dúvida” (NIEVA FENOLL, 2013, p. 13, tradução livre). Diante disso, poder-se-ia imaginar que o juízo sobre fatos e a valoração das provas seriam objeto de intensa preocupação pela doutrina e pela jurisprudência processual penal. Contudo, em realidade, tais questões findam por ser comumente estudadas sem maiores cautelas ${ }^{2}$ ou relegadas à aceitação do mito de uma convicção pessoal do magistrado, maculado por um subjetivismo exacerbado, quase místico (GASCÓN ABELLÁN, 2010, p. 12).

Sobre a temática, um dos principais pontos de discussão diz respeito aos critérios para que se possa afirmar um fato como provado, denominados standards probatórios. A partir deles, busca-se responder: quando se pode legitimamente afirmar que algo aconteceu? Ou, em termos simples, quantas e quais provas são necessárias para isso?

Afirma-se que o ordenamento processual penal brasileiro não possui previsão expressa de standard probatório para a condenação. ${ }^{3}$ Relata-se que "não há standard probatório legalmente previsto ou jurisprudencialmente adotado com uma formulação clara", de modo que os juízes recorrem a "critérios flexíveis de prova, com largo espaço para discricionariedade judicial” (BALTAZAR JR., 2007, p. 176).

No cenário internacional, a discussão tem sido objeto de maior atenção. Sem dúvidas, no debate sobre standards probatórios em matéria penal, a principal referência é o modelo estadunidense da "prova além da dúvida razoável". ${ }^{4}$ Entretanto, na doutrina, afirma-se que "o standard de prova em processos penais nos Estados Unidos é, como exposto, uma bagunça. Ele não é somente mal definido, mas também beira a arbitrariedade” (LAUDAN, 2006, p. 64, tradução livre).

1 Sobre a perspectiva histórica na construção do lastro probatório do processo, vide: Duclerc (2004, p. 02); Gomes Filho (1997, p. 18); e Lopes Jr. (2018, p. 341-350).

2 "Somando-se as três causas aqui identificadas $-1^{\circ}$ ) caráter refratário do direito probatório ao discurso jurídico; $2^{\circ}$ ) natural tendência ao subjetivismo; $3^{\circ}$ ) prevalência da tradição positivista - facilmente chega-se à consequência: a doutrina culminou por 'eclipsar e desvalorizar o aspecto normativo da teoria da prova judicial, certamente não eliminado, em que pese a abolição das provas legais', empobrecendo enfim o direito probatório" (KNIJNIK, 2007, p. 6).

3 Dispositivo relevante sobre a temática no CPP atual é o art. 155, que dispõe: "O juiz formará sua convicção pela livre apreciação da prova produzida em contraditório judicial, não podendo fundamentar sua decisão exclusivamente nos elementos informativos colhidos na investigação, ressalvadas as provas cautelares, não repetíveis e antecipadas”. Cita-se também o art. 386, VII, CPP: “O juiz absolverá o réu, mencionando a causa na parte dispositiva, desde que reconheça: [...] VII - não existir prova suficiente para a condenação”.

4 Sobre a discussão de sua caracterização como regra ou princípio, vide: Ferrua (2018, p. 112-114). 
Há, portanto, clara lacuna normativa e insuficiência doutrinária e jurisprudencial no Brasil, com um cenário de confusões e divergências na doutrina estrangeira. Diante disso, este artigo pretende analisar o standard probatório para condenação no processo penal. Para tanto, os problemas que o orientarão são: 1) É necessário adotar um standard probatório para condenação no processo penal brasileiro? 2) O standard de "prova além da dúvida razoável” é uma opção viável e pertinente? 3) Quais critérios podem ser utilizados para a definição de seu conteúdo?

Inicialmente, serão abordadas as teorias sobre valoração probatória, com o objetivo de assentar as premissas para a adoção de uma teoria racional da prova. Em seguida, as bases sobre o que é um standard probatório serão expostas para então se afirmar a necessidade de seu estabelecimento na dogmática processual penal. A partir disso, será explorada a categoria de "prova além da dúvida razoável" e suas principais críticas, para questionar a viabilidade e a pertinência de sua adoção no sistema brasileiro. Por fim, sustentando-se hipótese positiva, serão propostos critérios para sua definição e será esboçado projeto de reforma legislativa nesse sentido.

Em termos de limitações, este artigo não pretende aprofundar os importantes debates relacionados à verdade no processo penal, cuja produção bibliográfica é intensa e extrapola os objetivos desta pesquisa. ${ }^{5}$ Igualmente, aqui não serão discutidas as teorias relacionadas à probabilidade $^{6}$ e aos pressupostos filosóficos da razoabilidade, visto que, embora fundamentais à teoria racional da prova contemporânea,${ }^{7}$ demandam estudos que vão além dos contornos propostos pelos problemas aqui delimitados.

Existem diversos standards probatórios, os quais podem variar conforme a decisão que está sendo tomada e o seu momento procedimental. Por exemplo, deve-se diferenciar as situações de recebimento da denúncia, da pronúncia no júri e da sentença condenatória. Embora neste artigo se assentem bases úteis à discussão de um modo amplo, o foco será no standard necessário para a condenação criminal, ou seja, para a fragilização da presunção de inocência.

\section{VALORAÇÃo DA PROVA E CONSOLIDAÇÃO EPISTEMOLÓGICA DE UM MODELO RACIONAL E OBJETIVO DE JUSTIFICAÇÃO DA DECISÃO JUDICIAL SOBRE FATOS}

As discussões relacionadas às funções da prova no processo penal e à verdade na verificação judicial dos fatos são fontes de farta produção bibliográfica no Brasil e na doutrina estrangeira. ${ }^{\mathbf{8}}$

5 Em aprofundamento no que diz respeito à verdade no processo: Taruffo (2010); Ferrer Beltrán (2005); Grinover (2016); Khaled Jr. (2013); e Caprioli (2017).

6 Sobre isso, vide: Caprioli (2009, p. 56); Ferrer Beltrán (2007, p. 92-138); Gascón Abellán (2010, p. 46); Schiavo (2013, p. 54-99); e Sánchez-Rubio (2018).

7 Sobre proporcionalidade e razoabilidade, remete-se a: Atienza (1987); e Silva (2002).

8 Sobre isso: Badaró (2018); e Taruffo (2018). 
Certamente, inúmeras questões pertinentes surgem e é fundamental assentar que uma visão exacerbada que supervalorize a busca pela verdade no processo pode impactar premissas inadmissíveis no sentido de uma postura proativa do julgador para investigar os fatos com a pretensão de revelar tal verdade (LOPES JR., 2018, p. 378). Isso precisa ser criticado, em prol de um processo penal que efetivamente consolide a imparcialidade e o contraditório. ${ }^{9}$ Deve-se ter em mente que o processo determina uma "reconstrução histórica dos fatos" a partir de rastros do passado, de maneira que a versão adotada refletirá tal história de um modo analógico, mas nunca integral, abrangente e inquestionável (KHALED JR., 2013, p. 591). Ou seja, a função essencial do processo não pode ser concebida como a busca pela verdade, muito menos isso pode influenciar a postura do julgador. ${ }^{10}$

Por outro lado, mesmo os críticos da ideia de verdade no processo penal findam por conceber que "há uma exigência de fundo cognitivo a qual o juiz deve corresponder", pois ele "não dispõe de discricionariedade absoluta quanto ao acolhimento das representações narrativas que são introduzidas no processo” (KHALED JR., 2013, p. 551). ${ }^{11}$ Assim, a justiça criminal pressupõe um "cognitivismo processual na determinação do fato criminoso" (BADARÓ, 2016, p. 192), que requer a “verificabilidade ou refutabilidade das hipóteses acusatórias, em virtude de seu caráter assertivo, e sua comprovação empírica, em virtude de procedimentos que permitem tanto a verificação como a refutação” (FERRAJOLI, 2014, p. 40).

Embora se reconheça que, na prática judicial, a busca pelo convencimento e pela persuasão do julgador tenha um papel fundamental na orientação da atuação das partes processuais (LOPES JR., 2018, p. 344; MAYA e URANI, 2009, p. 40), não se pode negar que, em certa medida, o processo procura verificar uma hipótese acusatória, para que se autorize a imposição de uma sanção punitiva pelo Estado somente nos casos em que tenha ocorrido um fato criminoso, cuja autoria e materialidade restem provadas no processo. ${ }^{12}$

9 Sobre a importância do contraditório para a construção da decisão penal: Andrade (2017).

10 "Nesse panorama de incerteza epistemológica, o juiz não registra uma verdade objetiva, mas escolhe a hipótese mais provável. Em resumo, não investiga, mas decide” (IACOVIELLO, 1997, p. 12, tradução livre).

11 Conforme o autor, "não há como fugir da constatação de que a expulsão completa da verdade mataria a própria noção de motivação, o que com certeza seria conducente à maximização dos espaços potestativos de discricionariedade, algo absolutamente contrário aos propósitos de contenção regrada do poder punitivo" (KHALED JR., 2013, p. 550-551).

12 Sobre a análise da função da prova em seu duplo aspecto, cognitivista e persuasivo, adota-se a visão de que: "Por um lado, a visão cognitiva aporta contribuições ao ressaltar a importância de uma conexão instrumental com a realidade, para limitar o espaço decisório do juiz ao permitir um controle externo à motivação decisória, além de fundamentar as premissas epistemológicas da teoria da prova na dogmática processual penal. Contudo, tal postura tende a supervalorizar o papel da verdade no processo, abrindo brechas para abusos na proatividade do julgador, além de desconsiderar as limitações da pretensão de racionalidade da 
O fato de o juiz estar convencido é condição prática para a determinação da decisão, mas não é justificação legítima de seu conteúdo, ${ }^{13}$ pois "o convencimento psicológico do juiz é uma condição necessária, mas não suficiente” (BADARÓ, 2014, p. 262). A decisão do juiz precisa se pautar por critérios racionais e objetivos, pois somente assim se torna controlável (por ex., a partir do recurso sobre a condenação) (FERNÁNDEZ LÓPEZ, 2005, p. 238). ${ }^{14}$

Nesse sentido, em termos de valoração da prova, com a superação do sistema de prova tarifada, ${ }^{15}$ a adoção majoritária do "livre convencimento motivado" tem acarretado leituras abusivas: o "uso degenerativo que às vezes se faz desse princípio abre caminho para a legitimação da arbitrariedade subjetiva do juiz ou, no melhor dos casos, a uma discricionariedade que não se submete a critérios e pressupostos” (TARUFFO, 2011, p. 398, tradução livre). Isso porque se afastou um sistema criticável em que o julgador estava completamente vinculado por critérios de valoração prévia e abstratamente definidos na lei para consolidar um cenário de "livre convencimento", mas sem qualquer definição de critérios para orientar tal juízo sobre os fatos (NIEVA FENOLL, 2012, p. 65-66).

Diante disso, adota-se a proposta de uma teoria racional da prova, um "modelo segundo o qual os procedimentos de determinação dos fatos se dirigem à formulação de enunciados fáticos que serão verdadeiros se os fatos que descrevem tenham ocorrido ou sejam falsos em caso contrário" (GASCÓN ABELLÁN, 2010, p. 49, tradução livre), ${ }^{16}$ assumindo-se as limitações do conhecimento judiciário e, assim, adota-se uma noção de probabilidade (BADARÓ, 2014, p. 263; BADARÓ, 2016, p. 55). ${ }^{17} \mathrm{Ou}$ seja, afirma-se que um fato (“ $p$ ”) está provado quando "houver elementos de prova suficientes a favor de p" (FERRER BELTRÁN, 2005, p. 35, tradução livre), a partir de uma valoração orientada por critérios lógicos e objetivos, controláveis

modernidade e dos inevitáveis espaços de discricionariedade subjetiva do ato de julgar. A função persuasiva da prova, por outro lado, aporta o 'dado de realidade' ao estudo da teoria probatória, visto que considera as determinantes pessoais do juiz que podem influenciar na tomada da decisão. Embora tais elementos não se mostrem legítimos e suficientes para embasar o fundamento da prova, eles são circunstâncias que precisam ser sopesadas para permitir a devida compreensão das relações inerentes ao campo jurídico-penal. Por isso, também deve haver uma ligação cognitiva com os fatos, que aportará critérios e limitará o processo de convencimento do julgador” (VASCONCELLOS, 2018a, p. 715-716).

“[...] é inegável que fatores persuasivos ou retóricos existem na formação das provas em juízo. Contudo, o problema não é estabelecer se esses fatores existem, mas decidir se são importantes para justificar uma teoria 'retórica' da prova que possa ser assumida como dominante ou, inclusive, como teoria exclusiva e única da prova” (TARUFFO, 2011, p. 350, tradução livre).

Sobre o controle recursal e a valoração fática, vide: Vasconcellos (2019, p. 124-137 e 148-167).

15 Sobre as teorias de valoração probatória, vide: Amorim (2010); Hartmann (2003).

16 Sobre isso: González Lagier (2003).

17 Em crítica a tal posição: Khaled Jr. (2013, p. 184). 
intersubjetivamente. E, para tanto, o estabelecimento de standards probatórios, como se analisará neste trabalho, é passo fundamental para assentar as duas premissas (ZAZA, 2008, p. 11 e 16; PIERGALLINI, 2007, p. 595; LUCCHESI, 2019, p. 173).

\section{A NECESSIDADE DE ESTABELECIMENTO DE UM STANDARD PROBATÓRIO PARA A CONDENAÇÃO NO PROCESSO PENAL}

Os standards de prova são "critérios que indicam quando se conseguiu a prova de um fato, ou seja, critérios que indicam quando está justificado aceitar como verdadeira a hipótese que descreve” (GASCÓN ABELLÁN, 2005, p. 129, tradução livre). ${ }^{18}$ Trata-se, portanto, de padrões que apontam uma demarcação, um mínimo probatório que deve ser superado para que se considere um fato como provado. Em termos diretos, eles definem “o 'quanto de prova' (nível de suficiência probatória ou grau de confirmação” (KIRCHER, 2018, p. 190).

Importante ressaltar que, com isso, não se pretende um retorno ao sistema valorativo das provas legais. A diferença fundamental é que, nesse, a lei definia prévia e abstratamente quantos elementos e quais espécies probatórias deveriam estar presentes para a afirmação de um fato, vinculando completamente o julgador a tais critérios legalmente impostos. Por outro lado, em um sistema racional de valoração, os standards probatórios não enquadram o juiz em um esquema definido que determine quais e quantas provas específicas, mas afirma critérios para que, por meio de uma valoração racional de todo o lastro probatório, possa-se aceitar algo como comprovado. Em outros termos, é diferente impor por lei que a comprovação demanda necessariamente duas testemunhas oculares e definir que a prova deve sustentar o fato além da dúvida razoável.

Em uma análise ampla, os standards probatórios podem ser conceituados como "mecanismos para distribuição de erros" (LAUDAN, 2006, p. 68, tradução livre), ${ }^{19}$ pois, quanto maior for o rigor, ou seja, a quantidade/qualidade de provas necessárias para que se permita considerar um fato como provado, maior a tendência de que eventuais erros ocorram em casos de falsos negativos. Isso quer dizer que um standard mais rigoroso, como o "além da dúvida razoável”, ocasiona que exista uma segurança no sentido de que serão evitados ao máximo casos em que se considere como provados fatos que, em realidade, não ocorreram. Entre o erro de se declarar como provado um fato que não ocorreu ou não se aceitar o reconhecimento de algo que efetivamente tenha acontecido, opta-se por assentar que o sistema judicial deve se estruturar para evitar afirmar fatos falsos como verdadeiros.

18 De modo semelhante: Matida e Vieira (2019, p. 229).

19 Assim também: Ferrer Beltrán (2007, p. 143). 
Existem diversos standards probatórios possíveis, conforme o grau de dificuldade que se imponha para se aceitar um fato como provado. A definição do standard de prova, portanto, é uma escolha política e valorativa (ZAZA, 2008, p. 4; NARDELLI e MASCARENHAS, 2016, p. 56; BADARÓ, 2019, p. 249), sobre a distribuição de erros nos julgamentos pelo Estado, entre preferir um sistema que facilite que fatos sejam afirmados como provados ou outro que dificulte a sua comprovação e, assim, evite falsas afirmações judiciais. Justifica-se porque "uma distribuição de erro supõe uma determinada escolha (político-valorativa) sobre a intensidade com que se deve proteger os direitos e interesses afetados por cada um dos erros possíveis" (GASCÓN ABELLÁN, 2005, p. 130, tradução livre).

Isso, sem dúvidas, ocasiona relevantes impactos à esfera penal. Trata-se de uma "escolha política e moral plenamente compartilhável”, em que se opta por adotar um standard probatório para evitar que os erros judiciais prejudiquem o imputado inocente (TARUFFO, 2005, p. 117, tradução livre). Há aqui uma íntima relação com a presunção de inocência e com o ditame do in dubio pro reo, contudo é importante que se esclareçam algumas distinções.

Como pressuposto da justiça criminal de um Estado democrático de Direito, adota-se a premissa de que uma pessoa não pode ser considerada criminalmente culpada até que isso seja provado judicialmente (GIACOMOLLI, 2014, p. 89-96; ILLUMINATI, 1979, p. 86-69; FERRER BELTRÁN, 2018, p. 153-159). Ou seja, a presunção de inocência determina que o julgador adote uma postura de desconfiança e não aderência à versão acusatória, consagrando a sua imparcialidade (NIEVA FENOLL, 2013, p. 50). Isso acarreta consequências amplas à estruturação da teoria do processo penal, ${ }^{20}$ normalmente sistematizadas em três perspectivas, que impõem regras de tratamento, probatória e de juízo (ZANOIDE DE MORAES, 2010, p. 424-481): em resumo, o réu deve ser tratado como inocente até que se prove o contrário; a acusação deve provar licitamente as suas hipóteses incriminatórias (ônus da prova); e, no caso de dúvida, deve prevalecer a inocência (in dubio pro reo).

O standard probatório, contudo, não resta necessariamente definido a partir de tais premissas (BADARÓ, 2019, p. 247), o que ressalta a importância do debate sobre o tema. ${ }^{21}$ Trata-se de elemento distinto do in dubio pro reo. Este assenta que, em caso de dúvida, o réu deve ser absolvido, mas não especifica quando pode ser declarado ou superado o estado de dúvida (FERRER BELTRÁN, 2007, p. 145; CATALANO, 2016, p. 51-53). Ou seja, carece-se de um critério para atestar quando o lastro probatório é suficiente para afastar a presunção de

20 “[...] a presunção de inocência não é mais um princípio do processo, é o próprio processo. O princípio da presunção de inocência constitui uma proibição de desautorização ao processo" (SÁNCHEZ-VERA GÓMEZ-TRELLES, 2012, p. 37, tradução livre). Sobre isso, vide: Prado (2014, p. 18-19).

21 Contudo, há quem afirme que a adoção do standard de "além da dúvida razoável" é decorrência da presunção de inocência: Andrés Ibáñez (2009, p. 87-89). 
inocência. E, exatamente para tanto, "o critério de suficiência é o estabelecido pelo standard de prova" (NARDELLI, 2018, p. 300).

Assim, resta claro que o in dubio pro reo é insuficiente para determinar as balizas ao juízo condenatório, de modo que é necessário fixar um standard probatório, um nível de comprovação apto a legitimar a condenação. ${ }^{22}$ Entretanto, pode-se afirmar, desde já, que uma interpretação do sistema processual penal brasileiro atual impõe a adoção de um standard rigoroso, em reforço à presunção de inocência; por outro lado, é fundamental realizar uma alteração legislativa para inserir previsão de modo expresso e delimitar adequadamente o seu conteúdo. Em resumo, a regulamentação legislativa seria bem-vinda, mas não impede o aprimoramento da prática atual a partir da legislação vigente.

\section{O STANDARD DE “PROVA ALÉM DA DÚVIDA RAZOÁVEL" E OS PROBLEMAS EM RAZÃo DA FALTA DE DEFINIÇÃO DE SEU CONTEÚDO}

Como já afirmado, existem diversos standards probatórios, os quais são distintos conforme a espécie da decisão a ser tomada. Pode-se citar, por exemplo, os dois principais expostos na doutrina: preponderância de provas e prova além da dúvida razoável. Primeiramente, a ideia de "preponderância de provas", normalmente apontada como standard dos processos civis em geral, define que um fato pode ser considerado provado quando a sua ocorrência é mais provável do que sua não ocorrência (KNIJNIK, 2007, p. 37-38). Ilustrativamente, em termos quantitativos, costuma-se apontar a fração de $51 \%$ de certeza. ${ }^{23}$ Ou seja, analisando-se as diversas hipóteses, opta-se por considerar provada aquela que parece mais provável, ainda que as demais eventualmente também possam apresentar certo nível de confirmação pelos elementos produzidos no processo.

22 "Não somente a garantia não contempla uma proteção suficiente no sentido de exigir um padrão de constatação mais elevado para o processo penal, como também o próprio núcleo essencial da tutela da inocência se torna vulnerável e carente de uma proteção efetiva sem o estabelecimento claro de um standard probatório mais contundente" (NARDELLI, 2018, p. 297).

23 Sem pretensão de maiores aprofundamentos sobre as discussões relacionadas às teorias de probabilidade envolvidas na questão, a doutrina majoritária reconhece a impossibilidade de se fixar um percentual matemático de "certeza" necessária para que se atenda cada standard (FERRUA, 2018, p. 115). Assim, neste trabalho adota-se uma visão lógica de probabilidade, e a indicação de percentuais de certeza é somente ilustrativa para facilitar a compreensão. Nesse sentido, afirma-se que “os modelos de constatação, portanto, representam uma forma de viabilizar não um mecanismo de controle numérico-quantitativo - o que seria, obviamente, irrealizável -, mas uma pauta ou critério à luz do qual o juízo de fato possa ser formado e submetido ao contraditório" (KNIJNIK, 2007, p. 37). Sobre probabilidade lógica, vide: Ferrer Beltrán (2007, p. 92-138); Gascón Abellán (2010, p. 46); Schiavo (2013, p. 54-99). 
Por outro lado, há um standard mais rigoroso, geralmente indicado como característico de processos penais, que é o da “prova além da dúvida razoável”. Aqui há uma diferença em relação à "preponderância de provas”. Não se opta por aquela hipótese que parece mais provável, ainda que as demais possam também indicar certa probabilidade de ocorrência. A “prova além da dúvida razoável” determina que, para ser considerada provada, a hipótese precisa ter uma probabilidade bastante elevada de ocorrência e, além disso, as demais hipóteses alternativas não podem ser aceitáveis. Veda-se que exista qualquer dúvida razoável em relação à versão que se pretende afirmar como provada. Ilustrativamente, em termos quantitativos, discute-se o percentual de “certeza” necessário, que pode ser indicado na fração de $80 \%$, 90\% ou até 99\% (ZAZA, 2008, p. 7; MENDES, 2020, p. 113).

Trata-se de standard amplamente conhecido, especialmente por sua consolidação no sistema estadunidense, mas não só. Também foi adotado na Itália, a partir da reforma de 2006, a qual inseriu no art. 533 do CPP italiano que “o juiz pronunciará sentença condenatória se o imputado resultar culpado do crime imputado além de qualquer dúvida razoável”. ${ }^{24}$ Em âmbito latino, pode-se citar o CPP chileno, que, em seu art. 340, afirma: "Ninguém poderá ser condenado, salvo quando o tribunal, em seu julgamento, adquirir, além da dúvida razoável, a convicção de que realmente se cometeu o fato punível objeto da acusação e que nele tenha colaborado o imputado com uma participação culpável e apenada por lei”. ${ }^{25}$ Além disso, há regramento semelhante no Tribunal Penal Internacional, pois o Estatuto de Roma, em seu art. 66.3, dispõe que, "para proferir sentença condenatória, o Tribunal deve estar convencido de que o acusado é culpado, além de qualquer dúvida razoável”. ${ }^{26}$

Em caso julgado em 2015, Ruano Torres e outros vs. El Salvador, a Corte Interamericana de Direitos Humanos também adotou o standard de "prova além da dúvida razoável”, ressaltando sua importância em aplicação efetiva da presunção de inocência. Assentou-se que "o princípio da presunção de inocência requer que ninguém seja condenado, salvo se houver prova plena ou além de toda dúvida razoável de sua culpabilidade”. ${ }^{27}$

24 Disponível em: https://www.altalex.com/documents/news/2014/09/03/giudizio-sentenza. Acesso em: 10 jul. 2019 (tradução livre). Sobre isso: Zaza (2008, p. 15-16); Catalano (2016, p. 1-2); e Caprioli (2009, p. 52).

25 Disponível em: https://www.leychile.cl/Navegar?idNorma=176595. Acesso em: 10 jul. 2019 (tradução livre).

26 Disponível em: http://www.planalto.gov.br/ccivil_03/decreto/2002/D4388.htm. Acesso em: 10 jul. 2019. Sobre isso: Kircher (2018, p. 198-200); Pisani (2007, p. 1252).

27 CORTE IDH. Caso Ruano Torres e outros vs. El Salvador. Sentença de 5 de outubro de 2015. Serie C, n. 303, $\S 126$. Disponível em: http://www.corteidh.or.cr/docs/casos/articulos/seriec_303_esp.pdf. Acesso em: 10 jul. 2019. 
A concepção de que a condenação pressupõe prova “além da dúvida razoável” se pauta pela premissa de que as decisões judiciais e a valoração probatória envolvem juízos de probabilidade e que, assim, alcançar uma certeza absoluta é algo inviável (FERRER BELTRÁN, 2007, p. 47; GASCÓN ABELLÁN, 2005, p. 128). Ao se reconhecer que a certeza absoluta é inviável no processo decisório (CAPRIOLI, 2009, p. 54), a adoção de standards probatórios a partir de juízos de probabilidade limita a valoração em casos de excessos de rigidez para a declaração de fatos como provados (CATALANO, 2016, p. 72). Ou seja, considerando que dúvidas de diversas ordens sempre podem existir, definem-se critérios para assentar quando essa dúvida realmente pode ser considerada para fragilizar a comprovação de uma hipótese fática.

Em resumo, a partir desse standard, a hipótese fática deve ser considerada provada se não houver qualquer dúvida razoável quanto à sua veracidade. Contudo, inúmeras são as críticas que afirmam a sua inutilidade em razão da falta de definição clara de seu conteúdo (NIEVA FENOLL, 2013, p. 78; CAPRIOLI, 2009, p. 55-60; MULRINE, 1997, p. 209; SHEALY JR., 2013, p. 226-228; LAUDAN, 2005a, p. 99-100; BADARÓ, 2019, p. 249-253). Para analisar tal questão, deve-se expor brevemente as discussões nos Estados Unidos. ${ }^{\mathbf{2 8}}$

Conforme descrito por Laudan, inicialmente os jurados poderiam condenar em casos penais somente se houvesse uma certeza absoluta sobre a culpa do imputado. Contudo, percebendo-se que tal confirmação absoluta era inviável, adotou-se a ideia de "certeza moral", a qual, "embora aberta à dúvida dos céticos, em teoria, não apresenta fundamentos reais ou racionais para que seja duvidada na prática” (2006, p. 33, tradução livre). ${ }^{29}$

A partir do ano de 1850, os tribunais estadunidenses passaram a analisar casos relacionados com a discussão do standard probatório e surgiram menções à ideia de "dúvida razoável”. Em Commonwealth vs. Webster, a Suprema Corte de Massachusetts afirmou: "O que é uma dúvida razoável? É um termo bastante utilizado, provavelmente bem compreendido, mas não definido com facilidade. Não é somente uma mera dúvida possível; porque tudo relacionado a coisas humanas, e dependendo de comprovação moral, é passível de algumas dúvidas possíveis ou imaginárias. É o estado do caso que, após ter sido comparadas e consideradas todas as provas, deixa a mente do jurado sem condições de dizer que há uma condenação obrigatória, em uma certeza moral, da verdade da acusação. [...] Para tanto, não é suficiente estabelecer uma probabilidade, ainda que forte a partir da teoria das chances, de

28 Sem dúvidas, uma análise concreta em termos de direito comparado demandaria uma metodologia mais precisa de levantamento dos precedentes estadunidenses, mas, para os fins deste artigo, no sentido de apontar a confusão e a imprecisão que caracterizam o debate, se restringirá o exame a alguns casos citados como fundamentais pela doutrina de referência na temática.

Sobre isso, vide: Solan (1999, p. 111-112). 
que o fato imputado é mais provavelmente verdadeiro do que falso; mas a prova deve estabelecer a verdade dos fatos com uma certeza moral e razoável" ${ }^{30}$

Em 1894, a Suprema Corte estadunidense analisou o caso Dunbar vs. U.S., questionando uma condenação em que a instrução apresentada pelo juiz aos jurados foi "uma dúvida razoável não é uma dúvida irrazoável, ou seja, por dúvida razoável você não deve entender que todas as dúvidas devem ser excluídas; você deve decidir a questão submetida a partir de fortes probabilidades do caso, e as probabilidades devem ser fortes, não para excluir qualquer dúvida ou erro possível, mas para excluir uma dúvida razoável”. Diante disso, a Suprema Corte manteve a condenação e afirmou que tal instrução "fornecia toda a definição de dúvida razoável que uma Corte é obrigada a fornecer". ${ }^{31}$

Contudo, após diversos casos julgados nos anos posteriores, o precedente mais emblemático decidido pela Suprema Corte estadunidense foi In reWinship, de 1970, em que se estabeleceu claramente que o standard probatório em qualquer juízo criminal é o da "prova além da dúvida razoável". ${ }^{32}$ No caso concreto, um adolescente de 12 anos foi processado por subtrair dinheiro de uma carteira e condenado em decisão que utilizou o standard de preponderância de provas, conforme um estatuto de Cortes de Família de Nova York. O voto majoritário da Suprema Corte assentou que, embora em processos por delitos infracionais não seja necessário seguir estritamente o procedimento criminal, os elementos essenciais do devido processo precisam ser respeitados, de modo que o standard de prova além da dúvida razoável é fundamental e confere conteúdo concreto para a presunção de inocência, caracterizado como instrumento para reduzir o risco de condenações injustas. ${ }^{33}$

Todavia, embora consolidada a necessidade de atenção ao standard, ainda restava pendente a definição de seu conteúdo de modo mais concreto. E, nesse sentido, aponta-se que a doutrina e a jurisprudência estadunidenses apresentaram posicionamentos confusos e divergentes em muitos momentos. Afirma-se que "a Suprema Corte na última geração acarretou uma desconexão entre o standard de prova e as ideias filosóficas que originalmente assentavam suas premissas e sua coerência" (LAUDAN, 2006, p. 35, tradução livre).

Diversas conceituações surgiram entre julgados dos tribunais dos Estados Unidos, a partir de instruções fornecidas a jurados em juízos criminais. Exemplificativamente, cita-se a definição no sentido de que "prova além da dúvida razoável é aquela de um caráter de tanta

30 Disponível em: http://masscases.com/cases/sjc/59/59mass295.html. Acesso em: 10 jul. 2019 (p. 320, tradução livre). Sobre o precedente, na doutrina, vide: Dallagnol (2015, p. 269); Picinali (2010, p. 67-68).

31 Disponível em: https://supreme.justia.com/cases/federal/us/156/185/. Acesso em: 10 jul. 2019 (p. 156, tradução livre).

32 Sobre o caso, na doutrina brasileira: Baltazar Jr. (2007, p. 166-167).

33 Disponível em: https://supreme.justia.com/cases/federal/us/397/358/. Acesso em: 10 jul. 2019. 
convicção que você confiaria e agiria sem hesitação para tomar as decisões mais importantes da sua vida" (SOLAN, 1999, p. 114, tradução livre). Ou no sentido de que: "Dúvida razoável é a dúvida baseada na razão e no senso comum - o tipo de dúvida que faria uma pessoa prudente hesitar”. ${ }^{34}$ Diante da imprecisão e das divergências, existiram cortes que sugeriram aos juízes que simplesmente não oferecessem qualquer instrução sobre o standard probatório aos jurados, pois a definição de "dúvida razoável” seria autoevidente (LAUDAN, 2006, p. 48; MULRINE, 1997, p. 211; PICINALI, 2010, p. 68-69).

Assim, resta claro o cenário de confusões e imprecisões com relação à definição do standard probatório para condenação além da dúvida razoável (NEWMAN, 1993, p. 991; CATALANO, 2016, p. 39). E aqui isso pode ser destacado em razão do caráter subjetivista de todas as conceituações expostas (CAPRIOLI, 2009, p. 65; BADARÓ, 2019, p. 250). Essas construções focavam suas premissas no convencimento pessoal e subjetivo dos julgadores, ou seja, basicamente afirmam que o fato pode ser considerado provado quando os jurados estiverem assim convencidos de um modo consistente (NARDELLI e MASCARENHAS, 2016, p. 59). ${ }^{35}$

Há, portanto, uma inversão ou um ciclo vicioso incongruente em que se afirma que o julgador pode estar convencido quando estiver convencido. E aqui está o problema, pois um "standard probatório adequado não depende da confiança subjetiva de alguém em uma hipótese; pelo contrário, o standard nos diz quando nossa confiança subjetiva está justificada" (LAUDAN, 2006, p. 80, tradução livre). Assim, ausente um critério seguro de razoabilidade da dúvida, "essa formulação do standard de prova penal não consegue superar os problemas apontados na teoria da íntima convicção, de modo a se tornar imprestável como standard probatório” (FERRER BELTRÁN, 2007, p. 146, tradução livre).

Além disso, também em crítica afirma-se que a ideia de "prova além da dúvida razoável” acarreta uma inversão do ônus probatório, que no processo penal deve ser integralmente da acusação. A partir do momento em que se afirma que a condenação deve ser proferida se não houver dúvida razoável, desloca-se a atenção do jurado para a criação ou não de tal dúvida pela defesa, ou seja, afasta-se a devida consideração das provas incriminatórias que devem ser apresentadas pela acusação como premissa anterior (SOLAN, 1999, p. 119-131).

Nesse sentido, aponta-se que, em suas origens históricas, o conceito de "prova além da dúvida razoável” teria sido criado com o objetivo de facilitar a emissão de um juízo condenatório

34 Exemplificativamente, em termos semelhantes cita-se o documento de instruções em procedimentos de Júri preparado pelo $8^{\circ}$ Circuito de Corte de Apelações dos Estados Unidos, versão de 2017. Disponível em: http://www.juryinstructions.ca8.uscourts.gov/Criminal-Jury-Instructions-2017.pdf. Acesso em: 10 jul. 2019 (p. 92, tradução livre).

Sobre pesquisas empíricas que descrevem tal subjetividade conceitual, vide: Picinali (2010, p. 69-71). 
pelos jurados, que temiam represálias divinas em casos de erros (WHITMAN, 2008, p. 4-5; MARTIN, 2010, p. 227-230). Assim, afirma-se que o standard "constitui uma fórmula de compromisso e um auxílio de conformo moral ao julgador na situação em que é impossível alcançar a certeza matemática da prova” (CATALANO, 2016, p. 9, tradução livre). Com isso, autorizava-se que os jurados "pudessem condenar o acusado sem colocar em risco a sua própria salvação, desde que suas dúvidas não fossem 'razoáveis'” (WHITMAN, 2008, p. 3, tradução livre). Desse modo, afirma-se que "estamos utilizando o standard da dúvida razoável em uma função para a qual ele não foi originalmente estruturado, e de modo que ele cumpre tal objetivo de um modo previsivelmente disfuncional” (WHITMAN, 2008, p. 5, tradução livre).

Diante desses problemas, que ressaltam a fragilidade da construção do standard probatório da "prova além da dúvida razoável” mesmo em seu sistema jurídico de origem, deve-se questionar se há possíveis contribuições em sua implementação no modelo processual brasileiro. Assim, analisando as características de sistemas em que há julgamento predominante por juízes técnicos, com dever de motivação das decisões, questiona-se a viabilidade de sua definição a partir de critérios objetivos e racionais.

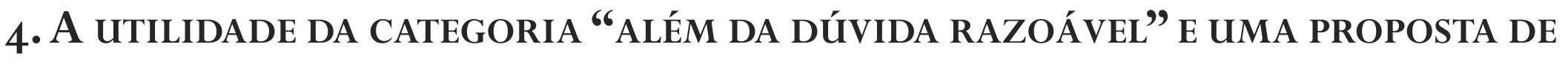 DEFINIÇÃO DE STANDARD PARA CONDENAÇÃO NO PROCESSO PENAL BRASILEIRO}

Sem dúvidas, as críticas expostas ao standard de “prova além da dúvida razoável”, especialmente em razão de sua imprecisão e consequente arbitrariedade, são relevantes e precisam ser consideradas. Contudo, pensa-se que há potencial para importantes contribuições ao sistema brasileiro, pois “os standards probatórios, quando adequadamente formulados, podem servir tanto como um critério de decisão capaz de orientar o raciocínio do julgador quanto como um método lógico hábil a indicar a estrutura a ser seguida quando da justificação da decisão, possibilitando um controle mais claro de seus fundamentos" (NARDELLI, 2018, p. $291-292){ }^{36}$

Primeiro, deve-se perceber que a construção estadunidense é fundamentalmente pautada por suas premissas assentadas em um sistema de julgamento por jurados, em que não há a imposição de um dever de motivação sobre a decisão condenatória. ${ }^{37}$ Lá afirma-se que

36 De modo semelhante: Gascón Abellán (2005, p. 129).

37 Mirjan Damaška desvela a relação entre as regras probatórias do sistema estadunidense com o sistema de júri adotado, em que há uma bifurcação de julgadores, ao passo que há um juiz togado que guia o processo e instrui os jurados, enquanto os julgadores leigos são aqueles que efetivamente decidem sobre o mérito do caso, ou seja, se o imputado é de fato culpado ou não. Conforme o autor, tal bifurcação de julgadores, em que o togado 
"o estudo da dúvida razoável precisa necessariamente estar relacionado com uma análise do júri” (SHAPIRO, 1991, p. 1, tradução livre). Portanto, houve a consolidação de visões subjetivistas na definição da "dúvida razoável”, pautando seu conteúdo no pressuposto de que o convencimento imotivado do jurado leigo é a base para a condenação, e seu juízo sobre os fatos é praticamente intangível a controles externos (TARUFFO, 2005, p. 119-121; CANZIO, 2004, p. 304).

A partir do exposto anteriormente com relação à teoria racionalista da prova, pensa-se que um standard probatório definido a partir de critérios objetivos pode consolidar fundamentais contribuições à dogmática processual penal e à racionalização do sistema criminal de um modo amplo. ${ }^{38} \mathrm{E}$ aqui a diferença fundamental é o dever de motivação imposto constitucionalmente a qualquer decisão judicial (art. 93, IX, CF) (NARDELLI, 2018, p. 302), em especial com relação ao juízo fático. ${ }^{39} \mathrm{Ou}$ seja, “o preceito da dúvida razoável deve, em primeiro lugar, ser inserido em um sistema de direito codificado, enquadrado em critérios de convencimento racional do juiz, fortemente fundamentado na obrigação de motivar” (CATALANO, 2016, p. 31, tradução livre).

Enquanto no sistema estadunidense "não é possível verificar se a prova além da dúvida razoável ou qualquer outro standard foi aplicado efetivamente pelos jurados, pela óbvia razão de que não motivam a decisão" (TARUFFO, 2005, p. 120, tradução livre), no ordenamento brasileiro a sentença condenatória precisa ser devidamente motivada, a partir de critérios técnicos e objetivos, e pode ser submetida ao controle por via recursal. Assim, em sistemas continentais, a assimilação da "dúvida razoável" como standard de prova pode resultar em "mecanismo mais garantista do que em sua própria criação nos sistemas de common law" (IGARTUA SALAVERRÍA, 2005, p. 143, tradução livre). Sua origem em razão do sistema bifurcado do júri dos Estados Unidos não impede que, a partir de leitura crítica, considerando tais distintas premissas, possa-se partir dessa construção para apresentar contribuições ao sistema brasileiro. ${ }^{40}$

instrui e seleciona as provas a serem apresentadas aos jurados, é que fundamenta a necessidade de instruções como a que é exposta com relação à valoração probatória e ao standard necessário para a condenação (DAMAŠKKA, 1997, p. 1-6 e 26-36). Sobre as distinções entre os sistemas, vide: Picinali (2010, p. 64-65).

“A regra de juízo do 'além da dúvida razoável' pretende (bem além da estereotipada afirmação do princípio do 'livre convencimento judicial') um percurso epistemologicamente correto, argumentações motivadas sobre as opções valorativas da prova, justificação racional da decisão, standards conclusivos de alta probabilidade lógica em termos de certeza processual, devendo-se reconhecer que o direito à prova, como expressão do direito de defesa, amplia o seu âmbito até a compreensão do direito da parte a uma valoração legal, completa e racional da prova” (CANZIO, 2004, p. 306, tradução livre).

39 Sobre o juízo fático e sua motivação: Andrés Ibáñez (1992).

40 Sobre direito comparado e importação de categorias, vide: Vieira (2018). Afirma-se: "O que não se pode admitir é que o critério de proof beyond reasonable doubt seja simplesmente transplantado de modo acrítico 
Sustenta-se, portanto, que a definição de um standard probatório para a decisão condenatória é primordial. ${ }^{41}$ Deve-se afastar a visão subjetivista, pois não é o convencimento pessoal que justifica a comprovação dos fatos, mas os elementos probatórios e sua valoração racional que precisam indicar quando o convencimento está justificado. ${ }^{42}$ Nesse sentido, a construção "prova além da dúvida razoável”, embora passível de críticas por sua indefinição, pode aportar contribuições, tendo em vista a sua utilização consolidada internacionalmente na teoria do processo penal. ${ }^{43}$ Ainda que Laudan defenda a necessidade de um novo standard, tendo em vista o esvaziamento do "prova além da dúvida razoável" (2005b, p. 153-155), pensa-se que há potencial espaço para aprimoramentos a partir da definição de seu conteúdo em termos ainda não concretizados nos exemplos indicados pelo autor, especialmente em ordenamentos em que há um dever forte de motivação das decisões judiciais. ${ }^{44}$

para o direito brasileiro, sem a devida verificação de compatibilidade de suas bases com as regras que regem o direito processual penal brasileiro" (LUCCHESI, 2019, p. 168). Mello e Gonçalves (2020, p. 325) defendem que "caso exista uma aplicação desse standard no direito brasileiro, a mesma deve seguir as diretrizes originárias do instituto, verificando sua origem e conceito, para que não se torne uma invenção de nossa prática (in)jurídica”. Contudo, como exposto neste artigo, a construção originária do modelo estadunidense é excessivamente subjetiva e imprecisa, visto que pautada por uma lógica de íntima convicção sem motivação na decisão dos jurados. Portanto, eventual aplicação no Brasil deve se orientar por uma maior precisão de seu conteúdo, com base em critérios mais objetivos e controláveis intersubjetivamente.

41 Há, contudo, quem sustente que o standard probatório para condenação criminal pode ser variável, conforme a complexidade e a espécie do delito em investigação (DALLAGNOL, 2015, p. 256-258, 267 e 272; FERRER BELTRÁN, 2007, p. 140-141). Por outro lado, não parece legítimo possibilitar uma variação do standard conforme a espécie e a complexidade do fato criminoso. Em qualquer situação, a acusação deve provar claramente todos os elementos de sua tese e essenciais ao tipo penal, e não pode haver uma hipótese alternativa de inocência viável, que apresente amparo probatório mínimo. O que pode, sim, variar é a possibilidade e a amplitude da utilização de provas indiciárias, além dos juízos inferenciais delas decorrentes. Em situações de complexidade e inviabilidade de comprovação direta, pode-se ampliar a consideração de provas indiciárias que permitam concluir pela ocorrência da tese acusatória e afastar qualquer hipótese alternativa de inocência viável, que apresente amparo probatório mínimo.

42 "Fora do Direito, os standards probatórios nunca são formulados em termos de confiança subjetiva dos pesquisadores, mas em termos de tipos de conexões lógicas que devem existir entre a prova disponível e as hipóteses em questão para se considerá-las provadas”(LAUDAN, 2005a, p. 105, tradução livre).

43 Pode-se citar, por exemplo, que o conceito de razoabilidade também é utilizado em outra construção importante ao processo penal, qual seja, da necessidade de julgamento em um prazo razoável. Embora também contenha tal conceito aberto, sua definição foi desenvolvida especialmente pela jurisprudência dos Tribunais Internacionais de Direitos Humanos, a partir de critérios objetivos, como a complexidade da causa, a atuação do Estado e da defesa, etc. Sobre isso: Catalano (2016, p. 12-17).

44 Em relação ao dever de motivação, intimamente associado com a proposta aqui apresentada, vale citar novo dispositivo inserido no CPP (art. 315, § $2^{\circ}$ ) pela Lei n. 13.964/2019, inspirado no art. 489, § $1^{\circ}$ do CPC/15. 
Além das críticas da doutrina estrangeira à construção do instituto e ao transplante jurídico entre ordenamentos, no Brasil também existem problematizações pertinentes. Aponta-se que a construção "além da dúvida razoável" tem sido, inclusive, utilizada em alguns tribunais ${ }^{45}$ sem a devida precisão de seu conteúdo. ${ }^{46}$ Assim, adverte-se que "o perigo para o qual queremos sinalizar é que o BARD termine funcionando como um 'anti-standard' de prova, passando a servir como um elemento puramente retórico de justificação das decisões, em nada diminuindo os espaços de subjetivismo, de discricionariedade ou mesmo de arbitrariedade que precisamente se quer evitar a partir da adoção de um modelo racionalista de prova" (MATIDA e VIEIRA, 2019, p. 224) ${ }^{47}$

Em razão da falta de precisão conceitual sobre o conteúdo de "prova além da dúvida razoável", nos termos já expostos nos itens anteriores, afirma-se que "o seu grau de indeterminação faz com que ele não ajude em nada na tarefa de exigir do julgador uma valoração racional da prova (baseada na contrastação das hipóteses e sem perder de vista a necessidade de um controle criterioso das inferências probatórias utilizadas)" (MATIDA e VIEIRA, 2019 , p. 242). Contudo, isso não obsta a tese sustentada neste artigo. Sem dúvidas, a construção atual do referido standard é evidentemente insuficiente e pode ocasionar prejuízos ao sistema brasileiro, diante de sua imprecisão e abertura, permitindo que se torne mero argumento retórico.

Sustenta-se a possibilidade de utilização da categoria "além da dúvida razoável" em razão de sua relevância e consolidação internacional, mas a partir de uma definição mais precisa de seu conteúdo, orientada pelos parâmetros da valoração racional da prova. Sem dúvidas, é impossível se definir um standard totalmente objetivo, pois na decisão judicial sempre haverá um espaço de subjetivismo (KNIJNIK, 2007, p. 46; NARDELLI e MASCARENHAS, 2016, p. 61). O que se deve buscar é reduzi-lo ao máximo possível. E, nesse sentido, o ponto central é a controlabilidade da decisão tomada pelo julgador (GASCÓN ABELLÁN, 2005, p. 129). A grande tarefa a ser enfocada ao se debater standards probatórios é a definição de balizas para que

Sem dúvida, a correta aplicação de um standard probatório efetivo e preciso depende da consolidação de um dever reforçado de motivação sobre o suporte fático para a sentença penal condenatória. Assim, a tese sustentada neste trabalho tem sua aplicabilidade aprimorada a partir dos referidos dispositivos já existentes no ordenamento brasileiro atual.

45 Cita-se o Supremo Tribunal Federal, que utilizou a categoria "além da dúvida razoável”, por exemplo, em diversos votos no caso Mensalão (AP 470). Sobre isso, vide: Matida e Vieira (2019, p. 233-237).

46 “Ao que parece, o recurso à expressão 'prova para além de dúvida razoável' tem sido utilizado como simples adorno retórico da decisão, sem que esteja cumprindo alguma efetiva função de controle” (LUCCHESI, 2019, p. 177).

47 BARD é a sigla em inglês utilizada para "beyond any reasonable doubt". Neste artigo, essa expressão foi traduzida como "prova além da dúvida razoável". 
a condenação possa ser controlada de maneira intersubjetiva, tanto internamente, pelas partes no processo, quanto externamente, pela sociedade (GOMES FILHO, 2013, p. 64-88). Nesse sentido, há uma forte relação da definição de um standard objetivo e do afastamento do subjetivismo na decisão judicial com o dever de motivação e o direito ao recurso no processo penal (GASCÓN ABELLÁN, 2010, p. 170-171; VASCONCELLOS, 2019, p. 147-179).

A partir da conclusão parcial de que o standard de "prova além da dúvida razoável” deve ser adotado no ordenamento brasileiro, sustenta-se que alguns parâmetros precisam ser atendidos para sua previsão normativa. Essencialmente, é importante ressaltar que sua definição deve se dar em dois momentos.

Primeiramente (1), para se evitar a crítica sobre inversão do ônus probatório exposta, deve-se regular que a parte acusatória (em regra, o Ministério Público) precisa comprovar todos os elementos de sua hipótese incriminatória de modo consistente, ${ }^{48}$ a partir de provas licitamente produzidas em contraditório. A hipótese acusatória deve ser capaz de explicar de modo coerente e íntegro todos os elementos fáticos comprovados no processo de um modo individual e específico, apresentando critérios confirmatórios disponíveis. ${ }^{49}$ Segundo Badaró (2019, p. 255), "para que um standard de prova seja completo, deve exigir provas que suportem todos os fatos alegados pela acusação e que sejam penal e processualmente relevantes".

Depois (2) - e aqui se coloca a diferença fundamental com o standard civil de "preponderância de provas",$-{ }^{\mathbf{5 0}}$ após comprovar consistentemente a hipótese incriminatória, deve-se

48 Um ponto de discussão na doutrina, que não será aqui aprofundado em razão dos limites do problema esboçado, é o ônus probatório de excludentes de ilicitude e culpabilidade. Sobre isso, remete-se a: Nogueira (2018).

49 Gascón Abellán expõe, exemplificativamente, alguns critérios de confirmação que devem ser sopesados para verificar a confiabilidade da hipótese: "O fundamento cognitivo das leis causais que conectam as provas com as hipóteses (é diferente que essas leis causais tenham um sólido fundamento científico, que sejam genéricas e imprecisas as máximas de experiência, ou que reproduzam simples tópicos ou preconceitos difundidos); a solidez epistemológica (grau de certeza) das provas que a confirmam (é diferente que a hipótese seja confirmada pelo resultado de um exame de DNA ou por um testemunho não tão sólido); o número de passos inferenciais que separam as provas das hipóteses (é diferente que a hipótese seja confirmada por uma prova direta ou por uma prova indiciária); a quantidade de provas ou confirmações (é diferente que a hipótese seja confirmada por somente uma, por algumas ou por várias provas); e a variedade de provas ou confirmações, pois a variedade proporciona uma imagem mais completa dos fatos (é diferente que a hipótese venha confirmada somente por testemunhas diretas ou por testemunhas diretas, provas científicas e provas indiciárias)" (GASCÓN ABELLÁN, 2005, p. 138, tradução livre).

50 A doutrina quase unanimemente afirma que o standard penal deve ser superior ao civil em geral, não bastando a hipótese acusatória ser somente a "mais provável”: Zaza (2008, p. 19-20 e 179); Canzio (2004, p. 304); Caprioli (2009, p. 54); Badaró (2019, p. 258). Em sentido diverso, Nieva Fenoll sustenta que o standard penal deve ser igualmente o de "preponderância de provas", pois seria contrafático um juiz dever 
afastar eventuais explicações alternativas para os fatos provados, ou seja, a tese incriminatória precisa resistir a qualquer dúvida razoável. Trata-se de uma verificação de falseabilidade da hipótese incriminatória (SCHIAVO, 2013, p. 91), em que se deve analisar a plausibilidade das hipóteses alternativas (CATALANO, 2016, p. 90; CANZIO, 2004, p. 304).

Como consequência, consolida-se o ônus probatório da acusação, também para afastar teses alternativas que questionem a resistência da hipótese incriminatória (CATALANO, 2016, p. 34). Além disso, reforça-se a posição de imparcialidade do julgador, pois é adotada uma "epistemologia falsificacionista", que "impõe ao juiz que assuma uma posição de incredulidade constante diante da hipótese acusatória, submetendo-a a sistemáticas tentativas de refutação” (NARDELLI, 2018, p. 304).

A questão mais problemática seria, contudo, definir o que é uma "dúvida razoável” que fragilize a tese acusatória e imponha a absolvição. Em termos gerais, dúvida "não é mais do que a indecisão de julgamento entre duas ou mais hipóteses" (NIEVA FENOLL, 2013, p. 19, tradução livre). Contudo, como já visto, o ato de julgar sempre é passível de dúvidas de diversas naturezas, de modo que não é qualquer desconfiança que pode justificar a absolvição. Afirma-se que é razoável a "dúvida palpável, justificada pelo conjunto probatório, por argumentos alternativos plausíveis ou pela possibilidade concreta de prova melhor" (NARDELLI, 2018, p. 301).

Segundo Badaró (2019, p. 260), “é necessário que seja uma hipótese sobre fatos concretos efetivamente suscitados pela defesa, ou mesmo que tenha surgido ao longo do processo (por ex., a partir da narrativa de algumas testemunhas, ou segundo um documento juntado nos autos) como uma hipótese viável, isto é, apta a explicar os fatos". Assim, pode-se definir dúvida razoável como a hipótese alternativa à tese incriminatória, que se mostre logicamente possível e amparada pelo lastro probatório do processo.

Diante das premissas assentadas e considerando formulações apresentadas pela doutrina analisada (FERRER BELTRÁN, 2007, p. 147; LAUDAN, 2006, p. 82-83; BADARÓ, 2019, p. 259), propõe-se os seguintes dispositivos legislativos, a serem inseridos no Código de Processo Penal:

Art. XX. Toda pessoa é presumidamente inocente até que se prove a sua culpa em definitivo, de modo que incumbe ao acusador provar todos os elementos de cada hipótese fática tipificada penalmente, autorizando-se a condenação somente se houver prova além da dúvida razoável de materialidade e autoria do crime.

absolver um imputado que acredita culpado e porque não se deveria adotar uma regra abstrata e absoluta para resolver os casos de dúvida (NIEVA FENOLL, 2013, p. 164-167). Trata-se de posição claramente questionável, que esvazia por completo a presunção de inocência, como regra probatória e de juízo, além de dissolver a importância do standard probatório no processo penal para distribuição democrática dos erros em juízo criminal. 
$\S 1^{\circ}$ A hipótese acusatória deve ser capaz de explicar de modo coerente e íntegro todos os elementos fáticos comprovados no processo, apresentando critérios confirmatórios disponíveis.

$\S 2^{\circ}$ Considera-se dúvida razoável a hipótese alternativa à tese incriminatória que se mostre logicamente possível e amparada pelo lastro probatório do processo.

$\S 3^{\circ}$ A sentença ou acórdão deve apresentar motivação fática consistente, a partir de critérios objetivos e racionais, indicando elementos probatórios que justifiquem cada afirmação fática e analisando eventuais hipóteses alternativas de potencial dúvida razoável.

\section{CONCLUSÕES}

Diante do exposto neste artigo, retomam-se os problemas que orientaram o seu desenvolvimento: 1) É necessário adotar um standard probatório para condenação no processo penal brasileiro? 2) O standard de “prova além da dúvida razoável” é uma opção viável e pertinente? 3) Quais critérios podem ser utilizados para a definição de seu conteúdo?

1. Diante da ausência de previsão legal expressa e delimitada no ordenamento brasileiro, é necessário que se regule um standard probatório para a condenação penal. Ainda que possa ser extraído implicitamente da presunção de inocência e do in dubio pro reo, pensa-se que tais preceitos não são suficientes para um adequado tratamento da matéria. A adoção de um standard probatório com critérios lógicos e objetivos é passo fundamental para a consagração de uma teoria racional da prova, em que se superem visões abusivas sobre discricionariedade judicial na valoração probatória ao juízo fático no processo penal. Trata-se de mecanismo para distribuição do erro nas decisões judiciais, que, no processo penal, consolida a escolha por um sistema racional para legitimação e limitação do poder punitivo estatal. ${ }^{\mathbf{5 1}}$

2. O standard de "prova além da dúvida razoável” é internacionalmente reconhecido e adotado por diversos países, mesmo em sistemas alheios à sua origem de common law, como Itália e Chile. Além disso, tal parâmetro está regulado no Estatuto de Roma, que assenta os procedimentos do Tribunal Penal Internacional, e é recomendado pela Corte Interamericana de Direitos Humanos. Ainda que existam críticas relevantes em relação à falta de definição de seu conteúdo, que ocasiona espaços para arbitrariedades no juízo fático, pensa-se que, em grande medida, isso é decorrência das premissas nas quais tal instituto foi estruturado, a partir da lógica de um sistema baseado em julgamento por leigos (jurados), que não possuem o dever de motivação. Contudo, sua adoção em sistemas continentais, em que o julgamento deve ser realizado por meio de critérios lógicos e técnicos, devidamente motivado 
e controlável por via recursal, pode aportar importantes contribuições à dogmática processual penal.

3. O standard para condenações penais deve ser superior àquele do âmbito civil, em regra definido como "preponderância de provas". Ou seja, para se superar a presunção de inocência, não basta que a hipótese incriminatória seja provável e possua confirmação em mais provas, é também necessário que eventuais hipóteses alternativas sejam afastadas. Embora a decisão judicial sempre possa ser permeada por dúvidas de diversas naturezas, inerentes ao pensar humano, se houver uma dúvida razoável a absolvição deve se impor.

3.1. A categoria "dúvida razoável" deve ser definida a partir de critérios objetivos e racionais, superando uma visão subjetivista que se foca simplesmente no convencimento obtido pelo julgador. Primeiro, deve partir da imposição do ônus da prova à acusação, sobre todos os elementos da hipótese incriminatória, relevantes penal ou processualmente ao processo, devendo ser ela capaz de explicar de modo coerente e íntegro os fatos comprovados no processo com a apresentação de critérios confirmatórios disponíveis. Então, após comprovar consistentemente a hipótese incriminatória, deve-se afastar eventuais explicações alternativas para os fatos provados, ou seja, a tese incriminatória deve resistir a qualquer dúvida razoável. A dúvida razoável pode ser definida como a hipótese alternativa à tese incriminatória que se mostre logicamente possível e amparada pelo lastro probatório do processo.

\section{AGRADECIMENTOS}

Este artigo foi desenvolvido no âmbito de estágio de pós-doutoramento realizado na Universidade Federal do Rio de Janeiro (UFRJ), sob a supervisão do prof. Dr. Geraldo Prado, a quem agradeço pela confiança e pela dedicação.

\section{REFERÊNCIAS}

AMORIM, Guilherme Freitas. Os controles de racionalidade na valoração da prova no processo penal. Revista de Estudos Criminais, Porto Alegre, v. 10, n. 36, p. 159-182, jan./mar. 2010.

ANDRADE, Flávio da Silva. A construção participada da decisão penal no Estado Democrático de Direito: a garantia de participação das partes, pelo contraditório, na composição da decisão justa e 
legítima. Revista Brasileira de Direito Processual Penal, Porto Alegre, v. 3, n. 3, p. 1007-1041, set./dez. 2017. https://doi.org/10.22197/rbdpp.v3i3.83

ANDRÉS IBÁÑEZ, Perfecto. Acerca de la motivación de los hechos en la sentencia penal. Doxa: Cuadernos de Filosofia del Derecho, n. 12, p. 257-299, 1992. https://doi.org/10.14198/doxa1992.12.08

ANDRÉS IBÁÑEZ, Perfecto. Prueba y convicción judicial en el proceso penal. Buenos Aires: Hammurabi, 2009.

ATIENZA, Manuel. Para una razonable definición de "razonable". Doxa, n. 4, p. 189-200, 1987. https://doi.org/10.14198/doxa1987.4.13

BADARÓ, Gustavo Henrique. Ônus da prova no processo penal. São Paulo: RT, 2003.

BADARÓ, Gustavo Henrique. Processo penal. 2. ed. Rio de Janeiro: Elsevier, 2014.

BADARÓ, Gustavo Henrique. A busca da verdade no processo penal e os seus limites: ainda e sempre o problema do prazo de duração da interceptação telefônica. In: SANTORO, Antonio E.; MADURO, Flávio M. (org.). Interceptação telefônica. Belo Horizonte: D’Plácido, 2016.

BADARÓ, Gustavo Henrique. Editorial dossiê “Prova penal: fundamentos epistemológicos e jurídicos”. Revista Brasileira de Direito Processual Penal, Porto Alegre, v. 4, n. 1, p. 43-80, jan./abr. 2018. https: / doi.org/10.22197/rbdpp.v4i1.138

BADARÓ, Gustavo Henrique. Epistemologia judiciária e prova penal. São Paulo: RT, 2019.

BALTAZAR JR., José Paulo. Standards probatórios no processo penal. Revista AJUFERGS, v. 4, p. 161 $-185,2007$.

CANZIO, Giovanni. L' "oltre il ragionevole dubbio" come regola probatoria e di giudizio nel processo penale. Rivista Italiana di Diritto e Procedura Penale, Milano, a. XLVII, p. 303-308, 2004.

CAPRIOLI, Francesco. L'accertamento della responsabilità penale "oltre ogni ragionevole dubbio". Rivista Italiana di Diritto e Procedura Penale, Milano, a. LII, p. 51-92, 2009.

CAPRIOLI, Francesco. Verità e giustificazione nel processo penale. Revista Brasileira de Direito Processual Penal, Porto Alegre, v. 3, n. 1, p. 317-342, jan./abr. 2017. https://doi.org/10.22197/rbdpp.v3i1.30

CATAlANO, Elena M. Ragionevole dubbio e logica della decisione. Milano: Giuffrè, 2016. 
DALlagnOl, Deltan M. As lógicas das provas no processo. Porto Alegre: Livraria do Advogado, 2015.

DAMAŠKKA, Mirjan R. Evidence law adrift. New Haven: Yale University Press, 1997.

DUCLERC, Elmir. Prova penal e garantismo: uma investigação crítica sobre a verdade fática construída através do processo. Rio de Janeiro: Lumen Juris, 2004.

FERNÁNDEZ LÓPEZ, Mercedes. Prueba y presunción de inocencia. Madrid: Iustel, 2005.

FERRAJOLI, Luigi. Direito e razão. Teoria do garantismo penal. 4. ed. São Paulo: RT, 2014.

FERRER BELTRÁN, Jordi. Prueba y verdad en el derecho. 2. ed. Madrid: Marcial Pons, 2005.

FERRER BELTRÁN, Jordi. La valoración racional de la prueba. Madrid: Marcial Pons, 2007.

FERRER BELTRÁN, Jordi. Uma concepção minimalista e garantista de presunção de inocência. Revista Brasileira de Direito Processual Penal, Porto Alegre, v. 4, n. 1, p. 149-182, jan./abr. 2018. https: //doi. org/10.22197/rbdpp.v4i1.131

FERRUA, Paolo. La prova nel processo penale. Revista Brasileira de Direito Processual Penal, Porto Alegre, v. 4, n. 1, p. 81-128, jan./maio 2018. https://doi.org/10.22197/rbdpp.v4i1.130

GASCÓN ABELLÁN, Maria. Sobre la posibilidad de formular estándares de prueba objetivos. Doxa, n. 28, p. 127-139, 2005. https://doi.org/10.14198/doxa2005.28.10

GASCÓN ABELLÁN, Maria. Los hechos en el derecho. Bases argumentales de la prueba. 3. ed. Madrid: Marcial Pons, 2010.

GIACOMOLLI, Nereu J. O devido processo penal. São Paulo: Atlas, 2014.

GOMES FILHO, Antonio Magalhães. Direito à prova no processo penal. São Paulo: RT, 1997.

GOMES FILHO, Antonio Magalhães. A motivação das decisões penais. 2. ed. São Paulo: RT, 2013.

GONZÁLEZ LAGIER, Daniel. Hechos y argumentos (Racionalidad epistemológica y prueba de los hechos en el proceso penal) (II). Jueces para la Democracia, v. 47, p. 35-51, 2003.

GRINOVER, Ada Pellegrini. Verdade real e verdade formal? Um falso problema. In: PEREIRA, Flávio Cardoso. Verdade e prova no processo penal. Brasília: Gazeta Jurídica, 2016. 
HARTMANN, Érica O. Os sistemas de avaliação da prova e o processo penal brasileiro. Revista da Faculdade de Direito UFPR, Curitiba, v. 39, p. 109-123, 2003. https: //doi.org/10.5380/rfdufpr.v39i0.1749

IACOVIELLO, Francesco M. La motivazione della sentenza penale e il suo controllo in cassazione. Milano: Giuffrè, 1997.

IGARTUA SALAVERRÍA, Juan. Prolongaciones a partir de Laudan. Doxa, n. 28, p. 141-150, 2005. https://doi.org/10.14198/doxa2005.28.11

ILLUMINATI, Giulio. La presunzione d'innocenza dell'imputato. Bologna: Zanichelli, 1979.

KHALED JR., Salah H. A busca da verdade no processo penal. Para além da ambição inquisitorial. São Paulo: Atlas, 2013.

KIRCHER, Luís Felipe S. O convencimento judicial e os parâmetros de controle sobre o juízo de fato: visão geral, direito comparado e o Tribunal Penal Internacional. Revista Due In Altum, v. 10, n. 20, p. 179 -206, jan./abr. 2018. https://doi.org/10.22293/2179-507x.v10i20.692

KNIJNIK, Danilo. A prova nos juízos cível, penal e tributário. Rio de Janeiro: Forense, 2007.

LAUDAN, Larry. Por qué un estándar de prueba subjetivo y ambiguo no es un estándar. Doxa, n. 28, p. 95-113, 2005a. https://doi.org/10.14198/doxa2005.28.08

LAUDAN, Larry. Una breve réplica. Doxa, n. 28, p. 151-155, 2005b. https://doi.org/10.14198/ doxa2005.28.12

LAUDAN, Larry. Truth, error, and criminal law. An essay in legal epistemology. Cambridge: Cambridge University Press, 2006. https://doi.org/10.1017/cbo9780511617515

LOPES JR., Aury. Direito processual penal. 15. ed. São Paulo: Saraiva, 2018.

LUCCHESI, Guilherme B. O necessário desenvolvimento de standards probatórios compatíveis com o direito processual penal brasileiro. Revista Brasileira de Ciências Criminais, São Paulo, v. 156, p. 165-188, jun. 2019.

MARTIN, Brian. Beyond reasonable doubt. Northern Territory Law Journal, v. 1, p. 225-251, 2010.

MAYA, André M.; URANI, Marcelo F. O princípio da identidade física do juiz e a função persuasiva da prova no processo penal. In: FAYET JR., Ney; MAYA, André M. (org.). Ciências penais e sociedade complexa II. Porto Alegre: Nuria Fabris, 2009. 
MATIDA, Janaina;VIEIRA, Antonio. Para além do BARD: uma crítica à crescente adoção do standard de prova "para além de toda a dúvida razoável" no processo penal brasileiro. Revista Brasileira de Ciências Criminais, v. 156, p. 221-248, jun. 2019.

MELLO, Sebástian Borges de Albuquerque; GOLÇALVES, Alana Stefanello. Suficiência probatória no direito criminal brasileiro: descaracterização do standard probatório beyond a reasonable doubt. Revista Brasileira de Ciências Criminais, v. 167, p. 303-328, mai. 2020.

MENDES, Paulo de Sousa. O standard de prova e as probabilidades: uma proposta de interpretação inspirada no direito comparado. In: AMBOS, Kai; MALARINO, Ezequiel (ed.). Fundamentos de direito probatório em matéria penal. São Paulo: Tirant lo Blanch, 2020. p. 95-116.

MULRINE, Thomas V. Reasonable doubt: how in the world is it defined? American University International Law Review, v. 12, n. 1, p. 195-225, 1997.

NARDELLI, Marcella A. M. Presunção de inocência, standard de prova e racionalidade das decisões sobre os fatos no processo penal. In: SANTORO, Antonio Eduardo R.; MALAN, Diogo R.; MADURO, Flávio M. (org.). Crise no processo penal contemporâneo. Belo Horizonte: D’Plácido, 2018. p. 289-309.

NARDELLI, Marcella A. M.; MASCARENHAS, Fabiana A. Os standards probatórios como métrica da verdade: em busca de parâmetros objetivos para a racionalização das decisões sobre os fatos. Revista del Instituto Colombiano de Derecho Procesal, Bogotá, n. 44, p. 45-66, jul./dez. 2016. https: // doi.org/ 10.32853/01232479.v44.n44.2016.425

NEWMAN, Jon O. Beyond “reasonable doubt”. New York University Law Review, v. 68, n. 5, p. 979 -1002, 1993.

NIEVA FENOLL, Jordi. La valoración de la prueba. Madrid: Marcial Pons, 2012.

NIEVA FENOLL, Jordi. La duda en el proceso penal. Madrid: Marcial Pons, 2013.

NOGUEIRA, Rafael F. Ônus da prova das excludentes de ilicitude no processo penal e a necessidade de rompimento com a sua matriz civilista. Revista Brasileira de Direito Processual Penal, Porto Alegre, v. 4, n. 1, p. 243-275, 2018. https://doi.org/10.22197/rbdpp.v4i1.124

PICINALI, Federico. Is "proof beyond a reasonable doubt” a self-evident concept? Considering the US and the Italian legal cultures towards the understanding of the standard of persuasion in criminal cases. Sistema Penal \&Violência, Porto Alegre, v. 2, n. 1, p. 64-82, jan./jun. 2010. 
PIERGALLINI, Carlo. La regola dell'“oltre ragionevole dubbio” al banco di prova di un ordinamento di civil law. Rivista Italiana di Diritto e Procedura Penale, Milano, a. L, p. 593-647, 2007.

PISANI, Mario. Riflessioni sul tema del “ragionevole dubbio”. Rivista Italiana di Diritto e Procedura Penale, Milano, a. L, p. 1243-1253, 2007.

PRADO, Geraldo. Prova penal e sistema de controle epistêmicos. São Paulo: Marcial Pons, 2014.

SÁNCHEZ-RUBIO, Ana. Los peligros de la probabilidad y la estadística como herramientas para la valoración jurídico-probatoria. Revista Brasileira de Direito Processual Penal, Porto Alegre, v. 4, n. 1, p. 183 -214, jan./abr. 2018. https://doi.org/10.22197/rbdpp.v4i1.118

SÁNCHEZ-VERA GÓMEZ-TRELLES, Javier. Variaciones sobre la presunción de inocencia. Análisis funcional desde el Derecho penal. Madrid: Marcial Pons, 2012.

SCHIAVO, Nicolás. Valoración racional de la prueba en materia penal. Buenos Aires: Del Puerto, 2013.

SHAPIRO, Barbara J. "Beyond reasonable doubt" and "probable cause". Historical perspectives on the AngloAmerican law of evidence. Berkeley: University of California Press, 1991.

SHEALY JR., Miller W. A reasonable doubt about "reasonable doubt". Oklahoma Law Review, v. 65, n. 2, p. 225-302, 2013.

SILVA, Virgílio A. O proporcional e o razoável. Revista dos Tribunais, v. 798, p. 23-50, 2002.

SOLAN, Lawrence M. Refocusing the burden of proof in criminal cases: some doubt about reasonable doubt. Texas Law Review, v. 78, p. 105-147, 1999.

TARUFFO, Michele. Tres observaciones sobre "Por qué un estándar de prueba subjetivo y ambiguo no es un estándar”, de Larry Laudan. Doxa, n. 28, p. 115-126, 2005. https: / / doi.org/10.14198/ doxa2005.28.09

TARUFFO, Michele. Simplesmente la verdad. Madrid: Marcial Pons, 2010.

TARUFFO, Michele. La prueba de los hechos. 4. ed. Madrid: Trotta, 2011.

TARUFFO, Michele. Hermenêutica, prova e decisão. Revista Brasileira de Direito Processual Penal, Porto Alegre, v. 4, n. 1, p. 129-148, jan./abr. 2018. https://doi.org/10.22197/rbdpp.v4i1.136 
VASCONCELLOS, Vinicius G. A prova no processo penal: a importância da valoração do lastro probatório e de seu controle por meio recursal. Revista Eletrônica de Direito da UFSM, Santa Maria, v. 13, n. 2, p. 695 -721, 2018a. http://doi.org/10.5902/1981369430012

VASCONCELLOS, Vinicius G. Fundamento e função do processo penal: a centralidade do juízo oral e sua relação com as demais fases da persecução penal para a limitação do poder punitivo. Revista Eletrônica de Direito Processual, v. 19, n. 2, p. 229-260, 2018b. http://doi.org/10.12957/redp.2018.31959

VASCONCELLOS, Vinicius G. Direito ao recurso no processo penal. São Paulo: RT, 2019.

VIEIRA, Renato S. O que vem depois dos "legal transplants"? Uma análise do processo penal brasileiro à luz de direito comparado. Revista Brasileira de Direito Processual Penal, Porto Alegre, v. 4, n. 2, p. 767 -806, maio/ago. 2018. https://doi.org/10.22197/rbdpp.v4i2.133

WHITMAN, James Q. The origins of reasonable doubt. Theological roots of the criminal trial. New Heaven: Yale University Press, 2008.

ZANOIDE DE MORAES, Maurício. Presunção de inocência no processo penal brasileiro: Análise de sua estrutura normativa para a elaboração legislativa e para a decisão judicial. Rio de Janeiro: Lumen Juris, 2010.

ZAZA, Carlo. Il ragionevole dubio nella logica della prova penale. Milano: Giuffrè, 2008.

\section{COMO CITAR ESTE ARTIGO:}

VASCONCELLOS, Vinicius Gomes de. Standard probatório para condenação e dúvida razoável no processo penal: análise das possíveis contribuições ao ordenamento brasileiro. Revista Direito GV, v. 16, n. 2, maio/ago. 2020, e1961. doi: http://dx.doi.org/10.1590/23176172201961.
Vinicius Gomes de Vasconcellos

Doutor em Direito pela Universidade de São Paulo (USP), com Período de sanduíche na Universidad Complutense de MAdRId (Espanha) (bOLSA PDSE/CAPES) E ESTÁGIO de Pós- doutoramento pela Universidade Federal do Rio de Janeiro (UFRJ). Mestre EM CIÊNCIAS CRIMINAIS PELA PONTIFíCIA Universidade Católica do Rio Grande do Sul (PUCRS). Professor permanente do InStituto Brasiliense de Direito Público (IDP/DF) (MEStrado/doutorado). Professor efetivo DA Universidade Estadual de Golás (UEG). EdITOR-CHEFE dA Revista Brasileira de Direito Processual Penal. Assessor de ministro no Supremo Tribunal Federal.

vinicius.vasconcellos@ueg.br 